\title{
ONLINE LEARNING ISSUES IN RUSSIAN UNIVERSITIES
}

\author{
PROBLEMAS DE APRENDIZAGEM ON-LINE NAS UNIVERSIDADES DA RÚSSIA
}

PROBLEMAS DE APRENDIZAJE EN LÍNEA EN LAS UNIVERSIDADES DE RUSIA

\author{
Gulnara Minshakirovna ILDUGANOVA ${ }^{1}$ \\ Nataliya Vladimirovna TIKHONOVA ${ }^{2}$ \\ Ruzilia Irekovna GALIMULLINA ${ }^{3}$
}

\begin{abstract}
There is considerable uncertainty as to the way we lead our lives. We face global changes concerning every single aspect of our lives: economy, digital technologies, cultures, languages, and even our health and, not to mention all the catastrophic consequences of the pandemic and economic slowdown. Institutions are responding to the current circumstances with a shift to online learning. While most universities have urgently switched to online learning and benefit from using educational and videoconferencing platforms, the issues caused by online education under these circumstances are still to be studied and carefully analyzed. This article problematizes the influence of online learning and reveals a range of pitfalls arising in the process of online education, as well as a detailed analysis of these issues. It was found out that the online learning process is affected by a wider range of reasons than we expected. The interrogative method was used as the main measurement tool. The evaluation studies were carried out at the university on its use of an online education system as a forced response to the current worldwide pandemic. Among the revealed issues, we established the following: students' ability to learn self-directly, assessment tools used by teachers to evaluate the knowledge, timely teacher's feedback, teachers' core competencies and personal qualities, technical, health issues, and some others. The global events caused such a situation that universities had to reconsider the way they deliver education to people. The goal is to make it more expedient, accessible, and personalized. The information in this paper can contribute to the quality improvement of online education and learning success.
\end{abstract}

KEYWORDS: Online learning. Online education. Involvement. Feedback. Self-directed education. Assessment. Teacher's core competencies. Student.

RESUMO: Existe uma incerteza considerável quanto ao modo como conduzimos nossas vidas. Enfrentamos mudanças globais relativas a cada aspecto de nossa existência: economia, tecnologias digitais, culturas, línguas e até mesmo nossa saúde e isso sem mencionar todas as consequências catastróficas da pandemia e da desaceleração econômica.

1 Kazan Federal University (KPFU), Kazan - Russia. Associate Professor of the Department of Foreign Languages and Professional Communication, Institute of Management, Economics and Finance. ORCID: https://orcid.org/0000-0002-3908-2926. E-mail: GMIlduganova@kpfu.ru

${ }^{2}$ Kazan Federal University (KPFU), Kazan - Russia. Head Professor of the Department of European Languages and Cultures, Institute of International Relations. ORCID: https://orcid.org/0000-0003-2112-4523. E-mail: nvtihonova@kpfu.ru

${ }^{3}$ Kazan Federal University (KPFU), Kazan - Russia. Head Professor of the Department of Foreign Languages and Professional Communication, Institute of Management, Economics and Finance. ORCID: https://orcid.org/0000-0002-4573-4783. E-mail: RIGalimullina@kpfu.ru

RPGE- Revista on line de Política e Gestão Educacional, Araraquara, v. 25, n. esp. 1, p. 516-527, mar. $2021 . \quad$ e-ISSN:1519-9029 DOI: https://doi.org/10.22633/rpge.v25iesp.1.14988 
As instituições estão respondendo às circunstâncias atuais com uma mudança para o aprendizado online. Embora a maioria das universidades tenha mudado urgentemente para o aprendizado online e se beneficiado do uso de plataformas educacionais e de videoconferência, as questões causadas pela educação online, sob estas circunstâncias, ainda estão para ser estudadas e cuidadosamente analisadas. Este artigo problematiza a influência do aprendizado online e revela uma série de armadilhas que surgem no processo de educação online, assim como uma análise detalhada destas questões. Descobriu-se que o processo de aprendizagem on-line é afetado por uma gama mais ampla de razões do que esperávamos. O método interrogativo foi usado como a principal ferramenta de medição. Os estudos de avaliação foram realizados na universidade, sobre o uso de um sistema de educação online como uma resposta forçada à atual pandemia mundial. Entre as questões reveladas, estabelecemos o seguinte: a capacidade dos alunos de aprender de forma autodirigida, ferramentas de avaliação utilizadas pelos professores para avaliar o conhecimento, feedback oportuno dos professores, competências essenciais e qualidades pessoais dos professores, questões técnicas, de saúde, e algumas outras. Os eventos globais causaram uma situação em que as universidades tiveram que reconsiderar a maneira como elas oferecem educação às pessoas. $O$ objetivo é torná-la mais ágil, acessível e personalizada. As informações contidas no documento podem contribuir para a melhoria da qualidade da educação on-line e para o sucesso do aprendizado.

PALAVRAS-CHAVE: Aprendizagem on-line. Educação online. Engajamento. Feedback. Educação autodidata. Avaliação. Principais competências do professor. Estudante.

RESUMEN: Existe una incertidumbre considerable en cuanto a la forma en que llevamos nuestras vidas. Nos enfrentamos a cambios globales en todos los aspectos de nuestras vidas: economía, tecnologías digitales, culturas, idiomas e incluso nuestra salud, y hoy sin mencionar todas las consecuencias catastróficas de la pandemia y la desaceleración económica. Las instituciones están respondiendo a las circunstancias actuales con un cambio hacia el aprendizaje en línea. Si bien la mayoría de las universidades se han cambiado con urgencia al aprendizaje en línea y se benefician del uso de plataformas educativas y de videoconferencia, los problemas causados por la educación en línea en estas circunstancias aún deben estudiarse y analizarse cuidadosamente. Este artículo problematiza la influencia del aprendizaje en línea y revela una serie de escollos que surgen en el proceso de educación en línea, así como un análisis detallado de estos temas. Se descubrió que el proceso de aprendizaje en línea se ve afectado por una gama más amplia de razones de las que esperábamos. Se utilizó el método interrogativo como principal herramienta de medición. Los estudios de evaluación se llevaron a cabo en la universidad sobre su uso de un sistema educativo en línea como respuesta forzada a la actual pandemia mundial. Entre los problemas revelados, establecimos lo siguiente: la capacidad de los estudiantes para aprender por si mismos directamente, las herramientas de evaluación utilizadas por los maestros para evaluar el conocimiento, la retroalimentación oportuna del maestro, las competencias básicas y las cualidades personales de los maestros, problemas técnicos, de salud y algunos otros. Los eventos globales provocaron una situación en la que las universidades tuvieron que reconsiderar la forma en que brindan educación a las personas. El objetivo es hacerlo más oportuno, accesible y personalizado. La información del documento puede contribuir a mejorar la calidad de la educación en línea y al éxito del aprendizaje. 
PALABRAS CLAVE: Aprendizaje en línea. Educación en línea. Participación. Comentarios. Educación autodirigida. Evaluación. Competencias básicas del maestro. Estudiante.

\section{Introduction}

Recent world events have once again shown close ties between global processes and educational systems. Almost all countries have been affected by the pandemic and had to take quarantine measures. 'Most governments around the world have temporarily closed educational institutions in an attempt to contain the spread of the COVID-19 pandemic. These nationwide closures are impacting almost $70 \%$ of the world's student population' according to UNESCO recent data.

Some countries refused to continue the educational process in an online format and even canceled the end of the school year exams and postponed the educational process for the next school year, while others quickly transformed the educational process to a remote online format. Switching to online learning conditioned by external circumstances was a forced but necessary measure.

It should be noted that in many Western countries university distance learning in the form of various massive open online courses as a part of education system is well-developed. Teachers and students there have all necessary skills to work and study online. Students can choose elective and even compulsory courses based on university online platforms without full-time class attendance. In the era of digital technologies, some Russian educational institutions have already been prepared for this type of educational work, but mainly these Digital Educational Resources placed on the official sites of universities nowadays only complement offline classes.

The transfer to the online platforms, without changing the interpersonal relations structure, brings to the organization completely new opportunities for management of relations, greater controllability and transparency (GLUKHOV, 2018).

University teachers had to reconsider their attitude to online learning. They were obliged to work without having digital skills, theoretical training, and an online learning methodology. But most of all, the unexpected changes affected students, for many of whom this switching has become a real stress

The teachers of higher educational institutions have to take into consideration the students' view on the learning process otherwise the vague ideas about the quality of 
interaction with students will directly affect the efficiency of education (MAKAROVA; SARTSEV, 2017).

When we talk about the interaction of students and teachers in the context of education it should be noted that this interaction is fruitful for both sides in case of a teacher's proper choice of the attitude to the object of communication, the student (RAZDORSKAYA et al., 2018).

This article further deconstructs the commonly held perception of factors influencing the educational process by presenting discourses about learning issues under the conditions of a sudden switch to online learning.

The results of our survey showed that the problem does exist. According to the research data, a part of students remains less involved in the learning process. Thus, the research question was revealed: 'What are the issues influencing online learning?'

It is the objective of this paper to identify those issues that may play a significant role in online learning.

\section{Methods}

In this research interrogative methodology in the form of questionnaire was used as the main tool.

The focus group consisted of 138 students of Kazan Federal University and was held on the basis of the Institute of Management, Economics and Finance which allowed collecting descriptive data from large scale of first and second year students.

The participants completed a survey assessing their point of views on issues they face in online environment and the advantages and disadvantages of online learning. The collecting of data was held anonymously on the basis of Google online questionnaire tool.

The questionnaire consisted of closed, dichotomous ('Yes/No'), multiple-choice, checkbox and Likert Scale types of questions. The use of open-ended questions allowed receiving more feedback from the respondents on the multiple personal issues influencing online learning process and the prospects of university online education.

The current research statements were developed by reviewing the scientific literature concerning online education barriers, trends and opportunities. 


\section{Results and discussion}

While switching to online learning, in order to explain the findings we need to take into consideration both the potential challenges and, subsequently, the issues or limitations inadvertently introduced by adopting new technologies or putting into practice particular pedagogical components (LEE, 2017).

After analyzing answers to the open-ended questions we found out that the level of involvement in online learning process is affected by wider reasons than we expected and with a view to discuss the results of the study we divided online learning issues as shown on the picture:

Figure 1 - Online learning issues as seen by the students.

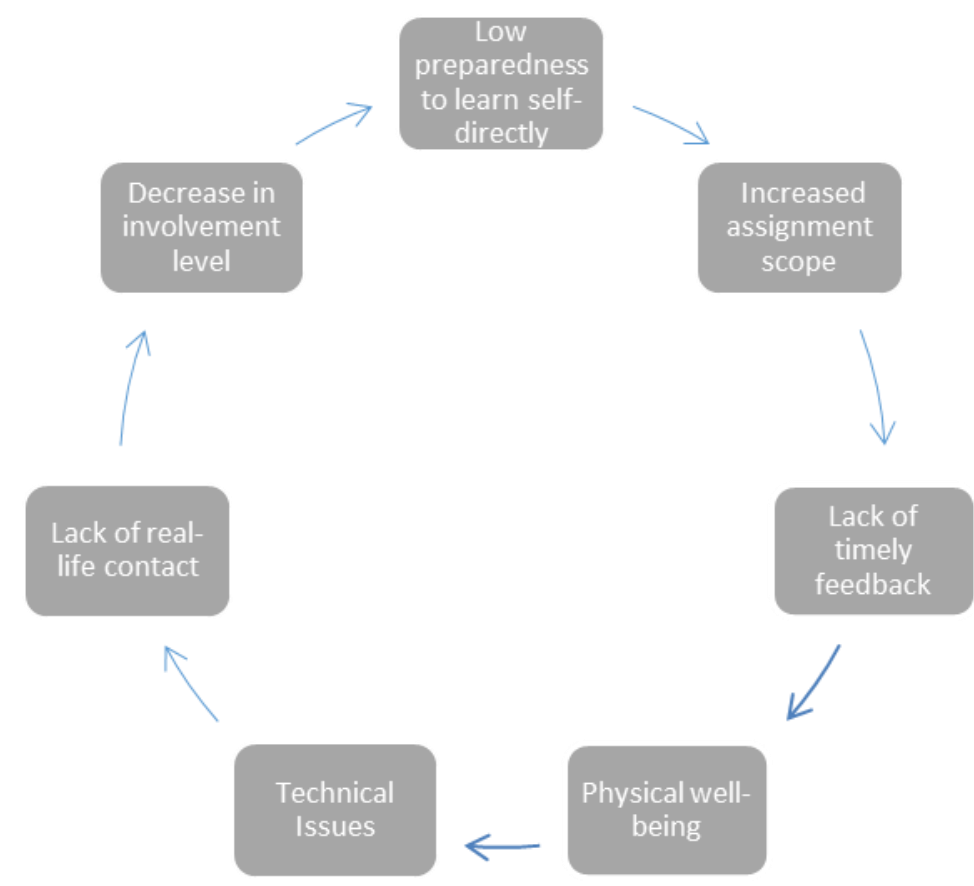

Source: Prepared by the authors

On a first-priority basis we considered the level of students' involvement in online learning process and the survey showed that the level of students' involvement varies. The majority of students, about $52 \%$, are equally involved in the learning process, as they were before. At the same time, a significant number of respondents $(35 \%)$ answered that they are less involved in online learning process.

Among these students, $50 \%$ are actively involved in the educational process during the online lessons, but $35 \%$ admit that they switch to the learning process only if a teacher directly appeals to them or asks something during the lesson. But conversely $23 \%$ of 
respondents admit that they keep simultaneously doing their own routine things not connected with the studies during online classes and $10 \%$ of them say that they are present at the lessons just as a mere formality.

It is necessary to mention that the sudden switch from offline to online education got stressed students who were not ready to change the manner of learning so quickly, as initially students chose the full-time education as a form of their studies at university. They were used to in-class learning with the presence of a teacher to lead them. However, the success in an online learning environment heavily relies on a student's ability to autonomously and actively engage in the learning process (WANG et al., 2013).

Some students note that online learning materials presented by teachers are not always shown in proper and convenient to study manner. 'Learner-content interaction was found to be the most important predictor of student satisfaction in fully online learning. This result suggests that instructors and instructional designers should pay attention to content design and selection of appropriate delivery technology in fully online settings. The online content should be (a) presented in an organized way and (b) easily accessed by online learners' (KUO et al., 2014).

After examining the results of the survey on students' ability to learn self-directly we found out the following: the answers indicated that only $24 \%$ of respondents do not have any problems with self-directed learning. Approximately the same number of students emphasizes that it is much easier to get teacher's explanations and ready-made class materials, than to search for the information independently. And $9 \%$ of respondents say that it is very difficult for them to study the materials by themselves and they need the full-time presence of a teacher and his or her personal explanations. However, students need to be independent in online learning process, as online education initially requires self-directed learning. Students have to acquire self-regulated learning strategies to achieve academic success within the online environment (BROADBENT; POON, 2015).

This situation deteriorates with serious increase in assignment scope $(74 \%$ of respondents). And despite the fact that many of them note, that the volume of tasks depends on the teacher $(27 \%)$ and in some cases the volume of tasks did not change $(16 \%)$, not a single respondent notes the decrease in assignment scope.

The increased assignment scope seduces some students to use plagiarism to cope with situation. It is quite difficult to check the ratio of students' independent fulfillment of the tasks within online learning environment. It should be noted that $56 \%$ of respondents say that they mostly carry out tasks on their own, but $52 \%$ among them still sometimes use the Internet 
sources if possible. This ratio can be seen as another indicator of proper self-directed learning skills of students.

Teacher is far not the only source of information nowadays. Thus, to improve the quality of education it is necessary to implement new learning approaches more adopted for the needs of students (TIKHONOVA; ILDUGANOVA; LUKINA, 2018).

In fairness, it should be noted that, according to the students' answers, teachers formulate the tasks in such a manner that mostly students are not able to find direct answers on the Internet and have to search for the necessary information and to analyze it on the selfdirected learning basis. $33 \%$ of students say that teachers have become more critical and demanding.

This can be explained again by the fact that online learning supposes getting knowledge mostly independently. Moreover, after sudden switch to online learning teachers, not being used to work online, placed stake on home assignments and especially on their scope in order not to lose control over the students and the process of education.

With this in view, the adequate students' knowledge online assessment became crucial. 'The selection of assessment techniques and appropriate assessment tools is an integral part of planning the e-learning processes' (ĆUKUŠIĆ; GARAČA; JADRIĆ, 2014).

According to the survey, students consider video interviewing online (43\%) and traditional self-assessment tests $(40 \%)$ to be the most efficient knowledge evaluation techniques.

$30 \%$ believe that project work is another credible tool of testing knowledge. However, a positive result of the project activities can be achieved only if the students realize opportunities of participating in such projects for their future educational and professional activities (TIKHONOVA; ILDUGANOVA; LUKINA, 2017).

However, one fifth of respondents think that in the conditions of online learning it is impossible to make a cold assessment of knowledge and validity and reliability of assessment in online environment are still issues to reconsider.

An integral part of the assessment procedure is devoted to feedbacks. The effective online assessment can foster a learner and assessment centered focus through formative feedback and enhance learner engagement with valuable learning experiences within the context of online formative assessment (GIKANDI; MORROW; DAVIS, 2011).

An effective formative feedback can help: to clarify goals, criteria and expected standards; to facilitate self-assessment in learning; to inform students about their learning in a high quality way; to encourage teacher and peer learning communication; to encourage 
positive motivation and self-esteem; to provide opportunities to improve previous results; to inform teachers what teaching techniques to use (NICOL; MACFARLANE-DICK, 2006).

The results shed some light on the role of peer and teacher's rationales in students' motivation level. Timely feedback from the teacher was named as the most important principle of communication between teachers and students by $60 \%$ of respondents. For $33 \%$ of students, it is equally important to receive approval and positive comments and feedbacks about their work from teachers and groupmates.

This suggests that in the conditions of online learning with a lack of face-to-face contact, praise and positive comments are an important factor for increasing the students' selfesteem and motivation. Together with it we doubt that online education can completely replace face-to-face teaching and learning (HEW; CHEUNG, 2014).

Students named teacher's qualities as another motivational factor. Considering the core competencies of a teacher, almost $73 \%$ of students recognize that the manner in which teaching materials are presented by a teacher plays a major role in online learning. In addition, the objectivity of knowledge assessment, the competence in the subject and general erudition of the teacher, which was mentioned by $60 \%$ of students, are important.

Half of the students note that most of the teachers clearly stipulate the rules for communication between students and teachers in online learning and $47 \%$ of students set aside the need to comply with the time frame when communicating with teachers as a good ethical skill.

Among other teacher' qualities that positively affect motivation and involvement in the educational process, willingness to help, interest in students' personality and their success rank the second place with $66 \%$.

But together with it $42 \%$ note that everything depends on the teacher's personality. Some respondents comment that teachers become more open and approachable to them with the switch to online form of education.

It is interesting to note that, as to the level of teacher's digital skills, only $20 \%$ of students say that developed teachers' skills in digital technologies are significant. They prioritize personal human qualities of a teacher over core and digital skills and competences.

Some other issues that students most often face in the process of online learning were revealed. Among them we can see a number of obvious reasons such as: poor Internet connection, malfunctioning of online learning platforms and gadgets, and inadequate home environment that does not allow participating entirely in online learning process, were indicated. 
If the above-mentioned tangible and technical problems can be eliminated in the future, we once again emphasize that the lack of face-to-face communication, which is mentioned by $40 \%$ of respondents, cannot be completely replaced in online learning environment. Students strongly need real-life communication with peers and teachers.

Providing students with a rationale, or explanation of why learning content may be useful, can enhance motivation. Both peer and instructor rationales positively influence students' interest in learning. Peer rationales may influence achievement by way of identification processes, while instructor rationales focus students' attention on content (SHIN; RANELLUCCI; ROSETH, 2017).

Students' physical well-being is another serious issue affecting the successful online education. Unfortunately, most of the students admit that they get much more tired while studying at home. It should be noted, that in conditions of self-isolation during the pandemic this has become not only an issue of online learning but a social problem of a global scale, which faced almost the entire population of our planet.

Although a considerable percentage of respondents $(17 \%)$ say that their physical condition has not changed and they do not feel much difference between being at home and studying at university, $21 \%$ of students say that they feel better being at home, which can be explained by more comfortable living conditions of some students comparing to, for instance, students in dormitories. Some students however noted the reduction of vision.

And in conclusion, while discussing the prospects of distance learning, students' opinions divided: $30 \%$ expressed their tough 'no' to further online learning, $10 \%$ are ready to switch to distance learning completely, $26 \%$ of the doubters have chosen the answer 'no, rather than yes' to online learning. $36 \%$ believe that it would be advisable to switch certain courses to online format.

Among the advantages of online learning, mentioned by all the students, one can find: saving time and money on daily commuting and the possibility to attend lectures and seminars without leaving the house. The last option is extremely valuable for foreign students and those who live in the remote parts of the country as historically online education was made to increase the accessibility of university education. Web-based learning provides flexibility and accessibility for students whose schedule or location makes it difficult to attend a physical class (WASCHULL, 2001).

Some students mention their time management improvements and the opportunity not to be late for the classes and the possibility to filter the information and not to listen to what you don't like. Among the advantages, the respondents also highlight the ability to record and 
re-view the lecture if necessary, accessibility of teachers for communication, opportunity to be engaged in additional self-development courses. All these positive changes contribute to the development of skills and core competencies.

There are categorically inclined students who see no advantages in online learning. Some noted not only the lack of advantages to mention but even the loss of acquired knowledge.

\section{Summary}

After analyzing the results of the survey we found out that the level of involvement in online learning process is affected by a wide range of issues: students' ability to learn selfdirectly, assessment tools used by teachers to evaluate the knowledge and added timely teacher's feedback, teachers' core competencies and personal qualities as students' motivation factors, technical, health issues and some others.

However, the positive trends of online learning are revealed by a significant number of respondents and they are ready to partly switch to online form of education in future.

\section{Conclusions}

We should admit that the situation in the world has completely changed for an uncertain period. Facing the dramatic transition to online learning, we have to revise the traditional pedagogical technics, methods and tools as well as to try to keep the education process at a proper level. The profound study of issues influencing the online learning process from the students' perspective might be very helpful to teaching staff of any educational institution.

We consider that there will be no complete return to traditional teaching forms in Russian universities after the tough period of drastic changes in the educational system. After having examined the survey results we believe that a part of university offline courses can be viable for online education in the future. After the detailed analysis of online learning issues, we established some positive dynamics. The conclusion relates mostly to theoretical courses and lectures rather than to practical courses. 
ACKNOWLEDGEMENTS: The work is performed according to the Russian Government Program of Competitive Growth of Kazan Federal University.

\section{REFERENCES}

BROADBENT, J.; POON, W. L. Self-regulated learning strategies \& academic achievement in online higher education learning environments: A systematic review. The Internet and Higher Education, v. 27, p. 1-13, 2015.

ĆUKUŠIĆ, M.; GARAČA, Ž.; JADRIĆ, M. Online self-assessment and students' success in higher education institutions. Computers \& Education, v. 72, p. 100-109, 2014.

GIKANDI, J. W.; Morrow, D.; Davis, N. E. Online formative assessment in higher education: A review of the literature. Computers \& education, v. 57, n. 4, p. 2333-2351, 2011.

GLUKHOV, A. P. Features of culture of virtual communications of generation z: management of communication regimes. Znak: Problemnoye pole mediaobrazovaniya, v. 4, n. 30, p. 157-166, 2018

HEW, K. F.; Cheung, W. S. Students' and instructors' use of massive open online courses (MOOCs): Motivations and challenges. Educational research review, v. 12, p. 45-58, 2014.

KUO, Y. C. et al. Interaction, Internet self-efficacy, and self-regulated learning as predictors of student satisfaction in online education courses. The internet and higher education, $\mathrm{V}$. 20, p. 35-50, 2014.

LEE, K. Rethinking the accessibility of online higher education: A historical review. The Internet and Higher Education, v. 33, p.15-23, 2017.

MAKAROVA, L. N.; SARTSEV, M. V. Problem zones of teachers and students' interaction. Social-economic phenomena and processes, v. 12, n. 5, p. 210-216, 2017.

NICOL, D. J.; MACFARLANE-DICK, D. Formative assessment and self-regulated learning: A model and seven principles of good feedback practice. Studies in higher education, v. 31, n. 2, p. 199-218, 2006.

RAZDORSKAYA, I. M. et al. Ethic aspects of the teachers and students interaction in the process of education. Karelian Scientific Journal, v. 7, n. 1(22), p. 53-56, 2018.

SHIN, T. S.; RANELLUCCI, J.; ROSETH, C. J. Effects of peer and instructor rationales on online students' motivation and achievement. International Journal of Educational Research, v. 82, p. 184-199, 2017.

TIKHONOVA, N. V.; ILDUGANOVA, G. M.; LUKINA, M. S. Implemented teaching methods based on interactive learning process in order to increase the ability of learning foreign language. The Journal of Social Sciences Research, p. 473-478, 2018. 
TIKHONOVA, N. V.; ILDUGANOVA, G. M.; LUKINA, M. S. Research projects as an effective practice of teaching ecological thinking through second language. Turkish Online Journal of Design Art and Communication, v. 7, p. 809-815, 2017.

WANG, J. et al. Meaningful engagement in Facebook learning environments: merging social and academic lives. Turkish Online Journal of Distance Education, v. 14, n. 1, p. 302-322, 2013.

WASCHULL, S. B. The online delivery of psychology courses: attrition, performance, and evaluation. Teaching of Psychology, v. 28, n. 2, p. 143-147, 2001.

\section{How to reference this article}

ILDUGANOVA, G. M.; TIKHONOVA, N. V.; GALIMULLINA, R. I. Online learning issues in Russian universities. Revista on line de Política e Gestão Educacional, Araraquara, v. 25, n. esp. 1, p. 516-527, mar. 2021. e-ISSN:1519-9029. DOI: https://doi.org/10.22633/rpge.v25iesp.1.14988

Submitted: $06 / 11 / 2020$

Required revisions: $18 / 01 / 2021$

Approved: $23 / 02 / 221$

Published: 01/03/2021 